\title{
Information Risk Conduction Mechanism between Oil Futures Market and Gold Market
}

\author{
Lihong Li \\ School of Business Administration \\ China university of Petroleum, CUP \\ Beijing, China \\ School of International Trade and Economics \\ University of International Business and Economics \\ Beijing, China
}

\begin{abstract}
Oil market and gold market both have the characteristics of commodity market and financial market. The paper analysis information risk transmission mechanism between crude oil futures market and gold futures market. On the selection of West Texas Intermediate crude oil futures and gold futures price data, the relationship between oil prices and gold prices by linear Engle-Granger cointegration association is analysised. The results show that the financial attributes of gold are stronger, and the volatility of gold futures prices will affect the volatility of oil futures prices. In the relaxation of confidence level, oil futures prices and gold futures prices show two-way linkages.
\end{abstract}

Keywords-crude oil futures; gold futures; information risk conduction; cointegration analysis

\section{INTRODUCTION}

Although the energy financial market is developed based on energy stock market, the size and influence of the energy market is more than the spot market with the continuous innovation of the financial products of the energy market as well as the perfection and transparency of the market trading rules. The oil financial market as an example, the current oil futures trading daily number 2 4 times daily global oil demand, oil financial market has become the stock market price changes of the vane, while the oil volatility in financial markets has been gradually out of stock market volatility, with risk yield curve of the financial market. The influence factors of energy financial market include the supply and demand situation of the energy spot market, the trend of global economic growth and so on.

In addition to its commodity attributes of gold, more important is the financial attributes. Unlike other precious metals such as silver, only about $15 \%$ of gold is used in industry, and it is used as a financial asset. In the Bretton Woods system, gold was pegged to the dollar. Although the collapse of the system in 1970 s, the price of gold has always been affected by the dollar, for gold is still denominated in dollars. There are many factors affecting the price of gold. The

This work was supported in part by the Program of Shale gas development economic boundaries and risk quantitative evaluation method under Grant 2016ZX05037006-003. price of gold is negatively related to the price of most financial assets, which can hedge against inflation and exchange rates and change in the opposite direction of the dollar index; the price of gold and oil prices move in the same direction. In addition, the real economy has indirect impact on gold prices.

Both oil and gold markets have the characteristics of commodity markets and financial markets. On the one hand, the change of its price is the result of the change of the supply and demand of the commodity itself. On the other hand, it is the result of the joint effect of the financial effect, the information effect and the speculative effect of the financial market. The pricing mechanism dominated by crude oil futures prices has an important impact on the real economy; Gold is an important investment and hedging tool in international financial markets.

The close relationship between the financial market and the financial market will bring more interaction. A market is affected not only by itself, but also by other market fluctuations.

The global energy finance market size and influence is growing. With the volatility of the global energy prices increasing, China's energy companies are facing enormous cost pressures. Global financial wealth distribution is passively accepted in China's financial market. The stability of the domestic financial system and national energy security are also affected by the global market. Because the development of China's energy finance lags behind, the energy industry has to bear the pain of price risk brought by the international energy market and the international financial market. Since the gold market is an important part of international financial market, which is similar to the oil market, it is of great significance to strengthen the price risk management of China's energy enterprises by studying the effect of price conduction under the condition of information spillover.

The spillover effect of market refers to the indirect impact of the transaction activities in a certain market. Spillover effects include information spillover effect, spillover effect and Risk Spillover effect. This paper is concerned with the price linkage between the oil market and the gold market because of two way information spillover effect. 


\section{LITERATURE REVIEW}

Many scholars believe that in recent years the rise in oil prices is the common market fundamentals of supply and demand and speculative forces results, but there are still disputes on the specific mechanism of action. Masters (2008) believes that speculation is the main force driving the rising oil prices in recent years. The Cifarelli and Paladino (2010) study also draws similar conclusions. Kilian (2009) believes that a sharp rise in oil prices in 2008 is due to the growing demand for oil in china. Kaufinann (2011) analysis the role of market fundamentals and speculation in the oil price, and the results show that the oil price volatility is due to two factors, among which, speculation is more and more important in the international oil price changes.

Many scholars have conducted the research from the analysis of the stock market, gold market, oil futures market, foreign exchange market and other financial market impact on the oil market. By studying the relationship between the oil market and the stock market, Ferson and Harvey (1995) and Kaneko and Lee (1995)find that there is an interaction between oil price and stock returns. Basher and Sadorsky(2006) use multi factor risk analysis model, through regression and non conditional logistic regression to examine the relationship between oil price risk and emerging stock market returns, research shows that has a significant impact on oil price fluctuation will emerging market stock market returns. Zhang and Fan (2008) find that there are three possible spillover effects between oil prices and the dollar, and there is a significant spillover effect between oil prices and the dollar. Cifarelli and Paladino (2009) found that the price change rate with the stock price change rate of exchange rate, price change rate has a significant negative correlation, and found evidence that the speculation does play an important role in the oil price volatility in recent years based on the international oil price from 1992 to 2008 with the multivariate financial method. Narayan (2010) research shows that there is a long-term co integration relationship between the international oil market and gold and oil futures and spot prices. For the relationship between speculative trading and oil price volatility in oil futures market, the conclusions are not consistent because of the different methods and data.

In the theory of financial market risk conduction, Liu ya, Zhang Shudong (2010) pointed out that the financial market indicators, including price, trading volume, etc., among them, the generalized financial market linkage effects include the linkage between financial assets price and its yield, volatility and trading volume. In the narrow sense of the financial market linkage effect, we must focus on the linkage between financial asset prices and returns, volatility. The financial market linkage effect widely appeared in various types of financial markets, for example, the linkage effect between foreign exchange market and the stock market, the linkage effects between futures market and spot market, and the linkage effect between different countries or regions of the financial market.

The research on the risk conduction between the gold market and the financial market as follows. Tan Yaling (2004) studies show that oil prices and gold prices are negatively correlated. Zhang Ying (2007) analysis shows that oil prices are the gold price of the reasons for the Grainger, using the error correction model and causality method to the data of international crude oil price and gold price in 2002-2006, there is a long-term equilibrium relationship between them. Baffes (2007) set up a logarithmic model for the international crude oil price and gold price in 1960-2005, and the research shows that the fluctuation of crude oil price will cause great reaction to the gold price. Hammoudeh and Yuan (2008) use GARCH and other econometric methods to analyze the data of international crude oil prices and gold prices in 1900-2006, the results show that the impact of crude oil price fluctuations on the gold yield is not significant. Paresh Kumar Narayan (2010) study shows that the long-term equilibrium relationship between gold and crude oil futures market, the existence of cointegration relationship between the two markets. Sarir (2010) use the method of generalized variance decomposition and impulse response function to test the influence of crude oil price fluctuation on metal price gains, and the results show that there is a significant positive correlation between metal price and crude oil price. Li Zhiguo (2012) empirical analysis of international crude oil prices, gold prices, the U.S. dollar index, the analysis shows that there is a long-term stable equilibrium relationship between crude oil prices and gold prices and the U.S. dollar index.

The template is used to format your paper and style the text. All margins, column widths, line spaces, and text fonts are prescribed; please do not alter them. You may note peculiarities. For example, the head margin in this template measures proportionately more than is customary. This measurement and others are deliberate, using specifications that anticipate your paper as one part of the entire proceedings, and not as an independent document. Please do not revise any of the current designations.

\section{THE TRANSMISSION MECHANISM OF INFORMATION RISK IN CRUDE OIL FUTURES MARKET AND GOLD FUTURES MARKET}

\section{A. The Transmission Mechanism of Financial Market Price Risk Caused by Information Spillover Effect}

The price change process is after all after obtaining new information and the constant pursuit of the balance of power, it is found that the results based on the theory of price discovery. There is a difference in the speed of response and the degree of response to the same information in different markets, which is mainly due to the difference of the maturity of the investors and the market. Sensitive and efficient market prices will be ahead of the slow pace of information capture and inadequate response to the market.

With the development of information technology and the formation of global economic integration, the research on the risk transmission mechanism between financial markets has become a hot topic. The flow of information in the market starts with a new information landing in a market, through arbitrage and speculation to achieve the price adjustment of the market. With the breaking of the information technology, when new information is passed to a certain financial market, the price of the financial products in the market will change. Because of the role of market integration, the financial market 
will change under the effect of information spillover. The higher the degree of market integration, the greater the likelihood of the same resource price convergence, the final result is no arbitrage opportunities between different markets. In a habit of traders in financial markets according to the price change in one market to other markets based dynamic, this behavior is a consequence of the local fluctuations quickly spread to other financial markets. When the phenomenon of information spillover exists in the two financial markets, the volatility of a market will not only have an inevitable impact on itself, but also will spread to other markets.

\section{B. The Price Risk Transmission of Oil Financial Market to Gold Market}

Petroleum financial market is the most mature and the largest market of energy derivatives in the financial market. It is also the highest degree of financial information spillover effect is more significant. In recent years, with the strengthening of the opening degree of the world's major oil markets, the trend of oil market integration is becoming stronger and stronger. The main reasons are as follows: First of all, oil is an international commodity, the basic trend of oil prices are driven by common factors, including production costs, OPEC policy, alternative energy prices and other factors; Secondly, the oil belongs to material goods, it is more easily affected by financial assets price rules; Thirdly, the world's major oil market openness is high, there is no barriers to access to investors; Finally, public information impacting on oil prices transfer between the markets simultaneously, arbitrage opportunities will induce investors to trade to make the price convergence of different oil markets (affected by the supply and demand factors of specific markets, transportation costs and taxes, the price of each oil market is not entirely consistent, but the basic trend of oil prices will show a high degree of convergence).

The new information will not only spread in the energy market, but also transfer the risk to other related markets. When external market information changes, information will have a certain degree of impact on the gold market. There are two possible ways for the conduction of the shock. One way, the information has a direct impact on the gold market and it causes the volatility of gold futures market. Another, the information has a impact on other international financial markets, crude oil futures market, through the spillover effect, the crude oil futures market will transfer the information to the gold futures market. The higher the degree of global financial integration, the higher the direct impact of the gold market will be affected by the impact of external information, and the indirect impact of the international financial market information transmission will be lower. It shows the trend of volatility spillover effect between international financial market and gold market.

\section{The price risk conduction of gold market to oil financial market}

The special attribute of gold determines its special purpose, and gold has three functions: reserve function, currency function and hedging function. In addition to its supply and demand factors, gold prices are also affected by the international financial markets. As one of the most important capital trading places in the world, the market price of gold market has changed dramatically with the supply and demand of market investors. The gold market has a relatively perfect trading system and convenient trading platform, therefore, the huge market size of the gold market, so that the price can fully reflect the market supply and demand.

The dollar is the main settlement currency of international crude oil and the main currency in the international gold market. The fluctuation of oil price and the fluctuation of gold price in the international crude oil market are closely related to the change of the value of the US dollar. Dollar as an intermediary, the price relationship between crude oil futures and gold futures is becoming more and more important.

In the long run, because the oil price is decided by supply and demand both sides decide the demand side, seemingly nothing, in fact, has also played a very important role. Due to the flow of information between the various markets, the correct grasp of the financial market information on the impact of the crude oil market, you can effectively avoid the low efficiency of crude oil supply. If the reaction speed of the gold market for market information faster than the oil market, on the one hand, the information will be transmitted to the oil market after a period of time; on the other hand, investors can change according to the price of the gold market in the oil market price forecast.

\section{AN EMPIRICAL MODEL OF INFORMATION TRANSMISSION MECHANISM IN CRUDE OIL FUTURES MARKET AND GOLD FUTURES MARKET}

An empirical study on the spillover effects between the two markets, have more consideration of the one-way influence oil prices on the gold market price, while ignoring the impact of gold futures price risk may have on the international oil futures market. When the international energy market or financial market events occur, the oil market and the gold market are not the same as the ability to disclose information and reaction speed, so there is a co integration relationship between oil price and gold market. In this paper, cointegration test is used to study the cointegration relationship between international gold price and international crude oil price, in order to reveal the information transmission mechanism of the financial market and the gold market.

\section{A. Data Sources and Description}

West Texas crude oil futures contract (WTI) and gold futures are financial products denominated in U.S. dollars, and are based on the transaction object. This paper selects the time span from 2002 to 2014, including several financial troughs and peaks, fully reflected the relationship between the two markets in the transmission of information risk.

This paper selects the West Texas crude oil futures contract (WTI) and gold futures price data, WTI transactions in the NYMEX market, gold trading in the COMEX market. Sample time span from November 21, 2002 to May 23, 2014, total of 2890 trading days. The traditional linear Engle- Granger cointegration analysis is used to study the co integration 
relationship between oil price and gold price and its influencing factors.

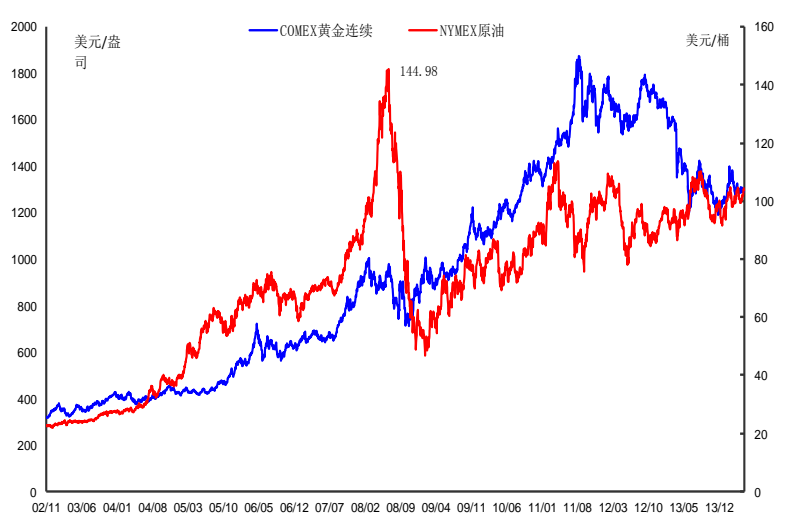

Fig. 1. NYMEX 2002-2014 crude oil futures prices and COMEX gold futures price chart.

As can be seen from "Fig. 1", from November 2002 to July 2008, COMEX gold futures contract price and NYMEX WTI futures contract price changes showed a positive correlation trend. In July 3, 2008, WTI futures prices rushed to the highest point of $\$ 144.98$ / barrel, the price began sharp decline, fell to 48.53 U.S. dollars / barrel after this period began to rebound, oil futures prices and gold futures price deviation. Gold futures prices in March 18, 2008 after breaking the thousand dollar mark showed a slight decline, but from the beginning of a new round of rising in September 2008. Review the history, in 2008 the U.S. subprime mortgage crisis sweeping the globe, the major financial institutions went bankrupt, brought huge impact to the world economy, causing volatility in international financial markets and energy prices, directly reflected in the price of gold and crude oil prices appear the abnormal relationship. In the sub loan crisis, compared with the gold market, the volatility of the oil market is more severe, reflecting the financial market is more vulnerable to the impact of specific events.

\section{B. Empirical Results}

The data are described by SPSS and Pearson correlation test. The results are shown in "Table I". The volatility of crude oil futures and gold futures prices are basically the same, skewness is negative, indicating that two groups of data are not concentrated, in line with the actual situation. In addition to the impact of the subprime mortgage crisis, the price of gold futures and crude oil futures price is a significant positive correlation, the correlation coefficient is 0.851 .

TABLE I. DEsCRIPTIVE STATISTICS OF CRUDE OIL Futures PRICE AND COMEX GOLD FUTURES PRICE

\begin{tabular}{|l|c|c|}
\hline & Crude oil futures price & Gold futures prices \\
\hline Observation number & \multicolumn{2}{|c|}{2890} \\
\hline mean value & 4.1793 & 6.7124 \\
\hline standard deviation & 0.4680 & 0.5330 \\
\hline skewness & -0.9744 & -0.186 \\
\hline kurtosis & 2.8554 & 1.6528 \\
\hline correlation coefficient & \multicolumn{2}{|c|}{$0.851^{* * * *}$} \\
\hline
\end{tabular}

the data is the result of the logarithm of the original data. * expressed at a $1 \%$ confidence
On the 2890 day of data using ADF method to test stationary of variables, "Table II" shows the critical value of unit root is larger than each confidence level in the price of gold futures and crude oil futures price series test, accept the null hypothesis, the two series are non-stationary series, meet the basic requirements of the cointegration test.

TABLE II. RESULTS OF ADF TEST

\begin{tabular}{|l|l|c|c|}
\hline & \multicolumn{1}{|c|}{$\begin{array}{c}\text { COMEX gold } \\
\text { futures prices }\end{array}$} & $\begin{array}{c}\text { NYMEX crude } \\
\text { oil futures prices }\end{array}$ \\
\hline \multirow{2}{*}{$\begin{array}{l}\text { Original } \\
\text { sequence }\end{array}$} & Check value & -1.61312 & -2.02944 \\
\cline { 2 - 4 } & The value of P & 0.4757 & 0.2742 \\
\cline { 2 - 4 } & Test results & Non-stationary & Non-stationary \\
\hline \multirow{2}{*}{$\begin{array}{l}\text { First order } \\
\text { difference } \\
\text { sequence }\end{array}$} & Check value & $-53.0156^{* * *}$ & $-59.7009 * * *$ \\
\cline { 2 - 4 } & The value of P & 0.0001 & 0.0001 \\
\cline { 2 - 4 } & Test results & stationary & stationary \\
\hline \multicolumn{2}{|c|}{ b. } & \multicolumn{2}{|c|}{ the price in the table is a logarithmic price; *** indicates a significant level of $1 \%}$.
\end{tabular}

The ADF test shows that the original sequences are nonstationary, and the first order difference sequence is smooth, which can satisfy the premise of co integration test for two sequences. Engle-Granger cointegration analysis steps are as follows:

First of all, the establishment of the regression equation between gold futures prices and crude oil futures prices:

$$
x_{1 t}=c+\beta x_{2 t}+e_{t}
$$

( $x_{1 t}$ for crude oil futures prices, $x_{2 t}$ for gold futures prices)

Then, the unit root test is performed on the residual sequence "Table III":

TABLE III. RESUlts OF ADF TEST FOR RESIDUAL SEQUENCE

\begin{tabular}{|c|c|c|c|}
\hline \multicolumn{2}{|c|}{$\begin{array}{c}\text { Augmented Dickey- } \\
\text { Fuller test statistic }\end{array}$} & t-Statistic & Prob.* \\
\cline { 2 - 4 } Test & $1 \%$ level & -2.056557 & 0.2627 \\
\hline \multirow{2}{*}{$\begin{array}{c}\text { critical } \\
\text { values }\end{array}$} & $5 \%$ level & -2.8623424 & \\
\cline { 2 - 4 } & $10 \%$ level & -2.567241 & \\
\hline
\end{tabular}

The results of ADF cointegration test, $t$ value of $-2.057, \mathrm{P}$ value of 0.2627 , reject the original assumption, the residual sequence is not stable. There is no cointegration relationship between crude oil futures prices and gold futures prices, which means that the international crude oil futures prices and gold futures prices do not show long-term equilibrium relationship in the sample time.

Because there is no long-term cointegration relationship between the gold market and the oil market, this paper only analyzes the Granger causality between them. Based on the test of unit root of first order difference sequence, we find that the first order difference sequence of the two sequences are both smooth, and the Granger causality test can be carried out. The test results are as follows:

As can be seen from "Table IV", at the $1 \%$ confidence level, the gold futures price is the Granger reason for the oil futures price changes. It can be seen that, compared with oil, gold 
financial attributes stronger, the volatility of gold futures prices will affect the volatility of oil prices. Because of the dramatic changes in the price of gold futures, the release of the value of gold stored in the currency properties, with the physical properties of the currency will also be the corresponding price volatility of oil, but lags behind the gold market. But if the confidence level is increased to $5 \%$, Oil futures price change is also the gold futures price changes of Granger reasons, it means that oil futures and gold futures prices cyclical mutual linkage trend is more and more obvious.

TABLE IV. RESUlts of Granger CAUSALity TeSt OF CRUDE OIL FUTURES PRICE AND GOLD FUTURES PRICE

\begin{tabular}{|c|c|c|c|}
\hline Original hypothesis & $\begin{array}{c}\text { Observation } \\
\text { number }\end{array}$ & $\begin{array}{c}\text { F } \\
\text { statistics }\end{array}$ & $\begin{array}{c}\text { The value } \\
\text { of P }\end{array}$ \\
\hline $\begin{array}{c}\text { Oil futures price is not the } \\
\text { Granger reason of gold } \\
\text { futures price }\end{array}$ & & $3.4363^{* *}$ & 0.0162 \\
\cline { 1 - 1 } $\begin{array}{c}\text { gold futures price is not the } \\
\text { Granger reason of Oil } \\
\text { futures price }\end{array}$ & 2890 & $6.2105^{* * *}$ & 0.0003 \\
& &
\end{tabular}

\section{CONCLUSION}

The paper analysis information risk transmission mechanism between crude oil futures market and gold futures market. Based on the analysis of the transmission mechanism of oil futures and gold futures market and the price cointegration model, the following conclusions are drawn:

- In contrast, the stronger the financial attributes of gold, gold futures price volatility will affect the volatility of oil futures prices. In the relaxed confidence level, the price of the two showed a two-way linkage.

- It can be inferred that in the transmission of information risk, the gold market reaction to the information faster than the oil futures market. In most cases, the risk of information is transmitted from the gold market to the oil and financial markets; Of course, we can't rule out that the oil financial market is more sensitive to certain information, in this case, the risk of information can be transmitted from the oil financial markets to the gold market.

- There is a positive correlation between the price of gold futures and the price of oil futures, mainly due to the impact of changes in the U.S. dollar, global inflation, and the security situation in oil producing countries. When the dollar is strong and value-adding, it will inhibit the international gold futures prices. Oil futures market prices denominated in dollar will fall, the same direction with gold price changes. When global inflation, currency devaluation, purchasing power decline occur, oil futures market prices rise. Gold as a hard currency will be favored, futures prices rise. When crude oil prices rise, the main oil producing countries can get a lot of dollars. However, these areas are tense, the dollar exchange rate risk is uncertain, and directly promote the demand for oil producing countries, and led the gold futures market prices.
- According to the positive correlation between gold price and international crude oil price, we can consider the trend of gold price to forecast the trend of crude oil price, to avoid the fluctuation of oil price risk better, reduce the loss of China's crude oil import enterprises.

\section{ACKNOWLEDGMENT}

I acknowledge the contributions of anthors for their work on the related papers. I would like to thank an anonymous reviewer, the editor, and other helpful comments.

\section{REFERENCES}

[1] Filis G, Degiannakis S, Floros C. Dynamic correlation between stock market and oil prices: The case of oil-importing and oil-exporting countries [J]. International Review of Financial Analysis, 2011, 20(3): $152-164$.

[2] Basher S A, Sadorsky P. Oil price risk and emerging stock markets [J]. Global Finance Journal, 2006, 17(2): 224-251.

[3] Askari H, Krichene N. Oil price dynamics (2002-2006) [J]. Energy Economics, 2008, 30(5): 2134-2153.

[4] Bhar R, Malliaris A G. Oil prices and the impact of the financial crisis of 2007-2009 [J]. Energy Economics, 2011, 33(6): 1049-1054.

[5] Engle et al. Risk and volatility: conometric model and financial practice[J]. The America Economic Review,2004,94(3):405-420.

[6] Wei Weixian, Lin Feng. Fluctuation of oil price at home and abroad and its interaction [J]. economic research, 2007(12): 130-141.

[7] Liu Ya, Zhang Shudong. Linkage effect of domestic and foreign financial markets: theoretical basis and literature review [J]. scientific decision, 2010(8): 65-77.

[8] Zhang Ying, Xu Li, Chen Hongmin. Oil and gold industry price linkage relationship of [J]. financial research, 2007 (7): 35-39.

[9] Li Zhi. From the relationship between the dollar index, gold price and the price of crude oil to see the crude oil price system - micro data and policy implications of the [J]. economic issues, 2012(5): 14-19. 